\title{
EVALUASI KINERJA BIDAN DALAM PELAYANAN ANTENATAL MENGGUNAKAN PENDEKATAN BALANCED SCORECARD DI KABUPATEN BANJAR \& KABUPATEN BARITO KUALA TAHUN 2016
}

\author{
Rafidah $^{1}$, Rusmilawaty ${ }^{2}$ \\ 1,2 Poltekkes Kemenkes Banjarmasin Jurusan Kebidanan \\ Email: rafidahendro@gmail.com, rusmilawaty71@gmail.com
}

\begin{abstract}
ABSTRAK
Jumlah kematian bayi di Provinsi Kalimantan Selatan pada tahun 2015 masih cukup tinggi yaitu 515 orang, Pada tingkat kabupaten/kota, Kabupaten Banjar menduduki urutan pertama jumlah kematian bayi sebesar 64 kasus, Kabupaten Hulu Sungai Utara sebesar 61 kasus, Kabupaten Hulu Sungai Selatan sebesar 60 kasus dan Kabupaten Barito Kuala sebesar 58 kasus. Jumlah bidan sudah relatif tersebar di seluruh wilayah Kalimantan Selatan, namun belum mampu menurunkan jumlah kematian bayi terutama di Kabupaten Banjar dan Kabupaten Barito Kuala. Evaluasi perlu dilakukan terhadap kinerja pelayanan antenatal, untuk mendapatkan gambaran mengenai pelayanan antenatal secara komprehensif dapat menggunakan alat ukur yaitu balanced scorecard.

Penelitian ini bertujuan menggarambarkan evaluasi kinerja bidan dalam pelayanan antenatal care meliputi perspektif finansial, perspektif bisnis internal, perspektif

Rancangan penelitian ini adalah observasional dengan pendekatan deskriptif. Instrumen menggunakan balanced scorecard. Sampel berjumlah 156 orang ibu hamil, 3 orang kepala Puskesmas dan 3 orang bidan coordinator yang ada di Puskesmas Karang Intan Anjir Pasar dan Anjir Muara

Perspektif finansial berupa dana operasional untuk pelayanan antenatal bersumber pada dana BOK (Bantuan Operasional Kesehatan), Perspektif proses bisnis internal menunjukkan sebagian besar responden yang melakukan kunjungan/pemeriksaan antenatal mendapatkan pelayanan sesuai standar $10 \mathrm{~T}$ sebanyak 83 orang $(53,3 \%)$, Perspektif kustomer menunjukkan sebagian besar responden yang melakukan kunjungan/pemeriksaan antenatal tidak puas dengan pelayanan yang diberikan sebanyak 87 orang $(55,8 \%)$, perspektif pertumbuhan dan sumber daya manusia didapatkan pendidikan bidan sebanyak 2 orang $(67 \%)$ berlatar belakang Diploma IV Kebidanan dan 1 orang $(33 \%)$ berlatar belakang Diploma III Kebidanan.
\end{abstract}

Kata Kunci : Kinerja, Balanced Score Card

Poltekkes Kemenkes Banjarmasin Jurusan

Kebidanan JIn H. Mistar Cokrokusumo

Banjarbaru

Email : rafidahendro@gmail.com 
ABSTRACT : Number of infant deaths in South Kalimantan Province in 2015 was still quite high at 515 people, at the district / city level, Banjar Regency ranks first in the number of infant deaths by 64 cases, North Hulu Sungai Regency by 61 cases, South Hulu Sungai Regency by 60 cases and Barito Kuala District by 58 cases. The number of midwives has been relatively scattered throughout the South Kalimantan region, but has not been able to reduce the number of infant deaths, especially in the Banjar and Barito Kuala Regencies. Evaluation needs to be done on the performance of antenatal services, in order to get an overview of antenatal services comprehensively, it can use a measuring tool, namely the balanced scorecard.

This study aims to describe the performance evaluation of midwives inservices antenatal care including financial perspectives, internal business perspectives, perspectives

The design of this study was a descriptive approach. Instruments using balanced scorecard. The sample was 156 pregnant women, 3 Puskesmas heads and 3 midwives coordinators at Karang Intan Public Health Center Anjir Pasar and Anjir Muara

Financial perspective in the form of operational funds for antenatal services sourced from BOK funds (Health Operational Assistance), internal business process perspective showed most of the respondents who did antenatal visits / examinations received services according to the $10 \mathrm{~T}$ standard of 83 people (53.3\%), customer perspectives showed that most respondents who did antenatal visits / examinations were not satisfied with the services provided by 87 people ( $55.8 \%$ ), growth and human resource perspectives obtained by midwife education as much as 2 people (67\%) with a Diploma IV Midwifery background and 1 person (33\%) with a Midwifery Diploma III background.

\section{Keywords: Performance, Balanced Score Card}

\section{PENDAHULUAN}

Angka kematian Ibu (AKI) dan Angka Kematian Bayi (AKB) merupakan satu indikator derajat kesehatan masyarakat. Tingginya AKB akan menentukan derajat kesehatan anak, jika semakin tinggi angka kematian bayi maka semakin bayi maka semakin rendah derajat kesehatan anak. AKB merupakan indicator utama dalam menentukan derajat kesehatan di Indonesia, karena anak sebagai penerus generasi bangsa memiliki kemampuan yang dapat dikembangkan dalam meneruskan pembangunan bangsa. Hasil Survei Demografi Kesehatan Indonesia (SDKI) (BPS dan ORC Macro (2007)), menyatakan AKB di Indonesia mengalami penurunan yang lambat. Pada tahun 2007 AKB sebesar 34 per 1000 kelahiran hidup, tahun 2012 menurun sedikit menjadi 32 per 1000 kelahiran hidup angka ini masih jauh dari sasaran yang ditetapkan Rencana Pembangunan Jangka Menengah Nasional (RPJMN) 2009 yaitu 24 per 1000 kelahiran hidup pada tahun 2014 dan target Milineum Development Golds (MDGs) yaitu 23 per 1000 kelahiran hidup pada tahun 2015 (Bappenas,2005)

Tingginya AKB di Indonesia antara lain disebabkan rendahnya kesadaran masyarakat tentang kesehatan ibu hamil menjadi yang merupakan faktor penentu angka kematian dan kualitas pelayanan kesehatan ibu yang belum memadai, kondisi ibu hamil yang tidak sehat dan faktor-faktor determinan lainnya. Penyebab ini dapat diminimalisir apabila kualitas Antenatal Care dilaksanakan dengan baik Kualitas perawatan selama hamil dan persalinan sangat penting memenuhi standar pelayanan antenatal. Potensi dan tantangan dalam penurunan angka kematian ibu dan anak adalah jumlah tenaga kesehatan yang menangani kesehatan ibu khususnya bidan sudah relatif tersebar ke seluruh wilayah Indonesia, namun kompetensi masih belum memadai. Demikian juga secara kuantitas, jumlah Puskesmas PONED dan RS PONEK meningkat namun belum diiringi dengan peningkatan kualitas 
pelayanan. Peningkatan kesehatan ibu sebelum hamil terutama pada masa remaja, menjadi faktor penting dalam penurunan AKI dan AKB.

Upaya yang dilakukan untuk menurunkan AKI adalah pada tahun 2012 Kementerian Kesehatan Republik Indonesia bekerjasama dengan USAID melaksanakan program Expanding Maternal and Newborn Survival (EMAS) yang bertujuan untuk menurunkan AKI dan Angka Kematian Neonatal sebesar 25\% (Kemenkes RI, 2012).

Pelayanan antenatal di tingkat pelayanan dasar di puskesmas menjadi ujung tombak untuk menurunkan kesakitan dan kematian ibu dan bayi baru lahir. Kualitas Pelayanan Antenatal di puskesmas dapat dinilai melalui kinerja pelayanan petugas kesehatan. Bila kinerja rendah sedangkan tenaga dan dana yang digunakan besar, maka efektivitas dan efisiensi pelayanan rendah. Penelitian yang dilakukan didapatkan kualitas pelayanan antenatal yang tidak baik meningkatkan 2,3 kali terjadi kematian perinatal. Kualitas Pelayanan Kesehatan pada ibu hamil yang tidak berkualitas cenderung akan mengalami kematian perinatal sebesar 1,99 kali (Herusantosa,T., Hakimi, M., 2006).

Provinsi Kalimantan Selatan tahun 2015 Jumlah kematian bayi di Provinsi Kalimantan Selatan masih cukup tinggi yaitu 515 orang, penyebab tertinggi kematian bayi karena faktor lain-lain sebesar 224 kasus, BBLR sebesar 185 kasus dan 106 kasus karena asfiksia. Untuk tingkat kabupaten/kota, Kabupaten Banjar menduduki urutan pertama jumlah kematian bayi sebesar 64 kasus, Kabupaten Hulu Sungai Utara sebesar 61 kasus, Kabupaten Hulu Sungai Selatan sebesar 60 kasus dan Kabupaten Barito Kuala sebesar 58 kasus. Jumlah bidan sudah relatif tersebar di seluruh wilayah Kalimantan Selatan, namun belum mampu menurunkan jumlah kematian bayi terutama di Kabupaten Banjar dan Kabupaten Barito Kuala.

Masih tingginya angka kematian bayi di Provinsi Kalimantan Selatan, khususnya di Kabupaten Banjar dan Kabupaten Barito Kuala, maka evaluasi perlu dilakukan terhadap kinerja pelayanan antenatal, untuk mendapatkan gambaran mengenai pelayanan antenatal secara komprehensif dapat menggunakan alat ukur yaitu balanced scorecard yang terdiri dari perspektif kepuasan pelanggan, memotivasi pegawai, mengukur pencapaian kinerja keuangan dan membuat tujuan strategis untuk melakukan suatu perubahan yang diukur dari perspektif pertumbuhan dan pembelajaran, bisnis internal, pelanggan dan keuangan (Ernawati, 2008). Evaluasi kinerja pelayanan antenatal dengan menggunakan balanced scorecard merupakan suatu proses formal terhadap pelaksana kinerja dan akan dapat memberikan feed back.

\section{BAHAN DAN METODE}

Penelitian ini merupakan jenis penelitian observasional dengan rancangan deskriptif. Penelitian ini menggambarkan kualitas pelayanan antenatal, perspektif finansial, perspektif customer/ kepuasan pelanggan, perspektif bisnis internal, perspektif pertumbuhan dan sumberdaya manusia (pendidikan dan pelatihan). Instrumen yang digunakan diadopsi dari Solihin (2010) menggunakan indikator balanced scorecard.

Populasi penelitian ini adalah petugas KIA (bidan), pimpinan puskesmas, ibu hamil yang berkunjung ke puskesmas terpilih untuk mendapatkan pelayanan antenatal pada saat penelitian berlangsung berjumlah 160 orang. Teknik Sampling menggunakan Simple Ramdom Sampling untuk menentukan Puskesmas yang dipilih yaitu Puskesmas Karang Intan, Anjir Pasar dan Anjir Muara. Sampel dalam penelitian ini adalah 52 orang ibu hamil untuk masing-masing puskesmas, 1 orang kepala Puskesmas dan 1 oran bidan koordinator

\section{HASIL DAN PEMBAHASAN HASIL}

A. Kinerja Pelayanan Antenatal Care (ANC) 
Indikator yang digunakan dalam melakukan penilaian terhadap kinerja pelayanan antenatal (ANC) menggunakan 4 (empat) perspektif balanced scorecard, yaitu perspektif financial yang diukur anggaran yang digunakan untuk operasional kegiatan pelayanan antenatal, perspektif bisnis internal yaitu proses pelayanan antenatal sesuai standar 10T; perspektif customer (kepuasan pelanggan) indikator yang dinilai meliputi reliability, responsiveness, assurance, empathy dan tangibless; perspektif pertumbuhan dan sumber daya manusia indikator yang diukur adalah pendidikan dan pelatihan petugas (bidan) yang dapat menunjang pelayanan antenatal care.

1. Perspektif Finansial

Alokasi anggaran pembiayaan operasional program pelayanan antenatal di masukkan ke dalam anggaran BOK (Bantuan Operasional Kesehatan) tahun 2016 tersaji pada tabel 4.4 sebagai berikut :

Tabel 1. .Distribusi frekuensi Biaya Pelayanan Antenatal di Puskesmas Karang Intan, Puskesmas Anjir Muara Dan Puskesmas Anjir Pasar Tahun 2016.

\begin{tabular}{l|l|l|r}
\hline \multirow{2}{*}{ Pelayanan } & \multicolumn{3}{|c}{ Puskesmas } \\
\cline { 2 - 5 } & \multicolumn{1}{|c}{ Karang Intan } & \multicolumn{1}{c}{ Anjir Muara } & \multicolumn{1}{c}{ Anjir Pasar } \\
\hline ANC & Rp.11.000.100,- & Rp.12.400.000,- & Rp. 13.100.000,-- \\
\hline Bumil KEK & Rp. $1.900 .000,-$ & Rp. 1.780.000,- & Rp. 1.800.000,-- \\
\hline P4K & Rp. 4.800.000,- & Rp. 5.680.000,- & Rp. 5.800.000,-- \\
\hline Kelas Ibu hamil & Rp. 4.200.000,- & Rp. 3.990.000,- & Rp. 3.900.000,-- \\
\hline $\begin{array}{l}\text { Transport detekti ibu } \\
\text { hamil risiko tinggi }\end{array}$ & Rp. 45.000,- & Rp. 40.000,- & Rp. $40.000,-$ \\
\hline
\end{tabular}

Tabel 1 menjelaskan alokasi biaya pelayanan ANC yang terbesar pada Puskesmas Anjir Pasar sebesar Rp 13.100.000, alokasi biaya pelayanan Bumil KEK yang terbesar pada Puskesmas Karang Intan sebesar Rp 1.900.000, alokasi biaya pelayanan P4K yang terbesar pada Puskesmas Anjir Pasar sebesar Rp 5.800.000, alokasi biaya pelayanan kelas ibu hamil yang terbesar pada Puskesmas Karang Intan sebesar Rp 4.200.000 dan alokasi biaya transport deteksi dini ibu hamil resiko tinggi yang terbesar pada Puskesmas Karang Intan sebesar Rp 45.000

2. Perspektif Bisnis Internal

Pelayanan antenatal sesuai standar $10 \mathrm{~T}$ merupakan ketentuan yang ditetapkan oleh Kementrian Kesehatan (2010), yang diberikan kepada pelanggan (ibu hamil). Adapun standar pelayanan antenatal 10T meliputi : 1) Timbang berat badan dan ukur tinggi badan, 2) ukur Tekanan darah, 3) nilai sTatus gizi, 4) ukur Tinggi fundus uteri, 5) Tentukan posisi fundus uteri, 6) pemberian imunisasi Tetanus toksoid, 7) pemberian Tablet tambah darah, 8) Tes laboratorium sederhana ( $\mathrm{Hb}$, protein urin) dan atau atas indikasi 9HbsAG, HIV, Malaria, TBC), 9) Tatalaksana kasus, 10) Temu wicara.

Penilaian pelayanan antenatal sesuai standar $10 \mathrm{~T}$ kepada ibu hamil yaitu kepatuhan bidan dalam melaksanakan pelayanan antenatal sesuai standar 10T pada saat kunjungan ibu hamil dengan menggunakan kuesioner yang berisi 10 pertanyaan berdasarkan atas pelayanan yang diterima. Hasil penilaian dikategorikan sesuai standar dan tidak sesuai standar dapat dilihat pada tabel 4.2 berikut ini :

Tabel 2. Distribusi frekuensi Standar pelayanan antenatal 10T di Puskesmas Karang Intan, Puskesmas Anjir Muara Dan Puskesmas Anjir Pasar Tahun 2016. 


\begin{tabular}{l|c|c|c|c|c|c|c|c}
\hline \multirow{2}{*}{ Pelayanan Antenatal } & \multicolumn{6}{|c|}{ Puskesmas } & \multirow{2}{*}{ Jumlah } \\
\cline { 2 - 9 } & $\begin{array}{c}\text { Karang } \\
\text { Intan }\end{array}$ & \multicolumn{2}{|c|}{$\begin{array}{c}\text { Anjir } \\
\text { Muara }\end{array}$} & \multicolumn{2}{c}{ Anjir Pasar } & \multirow{2}{*}{} \\
\cline { 2 - 9 } & $\mathbf{f}$ & $\%$ & $\mathbf{f}$ & $\%$ & $\mathbf{f}$ & $\%$ & & \\
\hline Sesuai Standar 10 T & 34 & 65,4 & 24 & 46,1 & 25 & 48,1 & 83 & 53,3 \\
\hline Tidak Sesuai Standar 10 T & 18 & 34,6 & 28 & 53,8 & 27 & 51,9 & 73 & 46,7 \\
\hline Jumlah & 52 & 100 & 52 & 100 & 52 & 100 & 156 & 100 \\
\hline
\end{tabular}

Tabel 2, menunjukkan sebagian besar responden yang melakukan kunjungan/pemeriksaan antenatal di Puskesmas Karang Intan, Anjir Muara dan Anjir Pasar mendapatkan pelayanan sesuai standar $10 \mathrm{~T}$ sebanyak 83 orang $(53,3 \%)$.

3. Perspektif Kustomer (Kepuasan pelanggan)

Penilaian kepuasan pelanggan (ibu hamil) terhadap pelayanan antenatal oleh petugas (bidan). Penilaian kepuasan dilakukan kepada 156 orang ibu hamil dengan menjawab pertanyaan yang terdiri dari 22 item yang diberikan setelah pelayanan diterima oleh ibu hamil di Puskesmas Karang Intan, Puskesmas Anjir Muara dan Puskesmas Anjir Pasar. Hasil penilaian dikategorikan puas dan tidak puas dapat dilihat pada tabel 4.3 sebagai berikut :

Tabel 3. Distribusi frekuensi responden berdasarkan Kepuasaan Pelanggan di Puskesmas Karang Intan, Puskesmas Anjir Muara Dan Puskesmas Anjir Pasar Tahun 2016.

\begin{tabular}{|c|c|c|c|c|c|c|c|c|}
\hline \multirow{3}{*}{$\begin{array}{l}\text { Kepuasaan } \\
\text { Pelanggan }\end{array}$} & \multicolumn{6}{|c|}{ Puskesmas } & \multirow{2}{*}{\multicolumn{2}{|c|}{ Jumlah }} \\
\hline & \multicolumn{2}{|c|}{$\begin{array}{l}\text { Karang } \\
\text { Intan }\end{array}$} & \multicolumn{2}{|c|}{ Anjir Muara } & \multicolumn{2}{|c|}{$\begin{array}{l}\text { Anjir } \\
\text { Pasar }\end{array}$} & & \\
\hline & $f$ & $\%$ & $f$ & $\%$ & $f$ & $\%$ & $f$ & $\%$ \\
\hline Puas & 15 & 28,8 & 20 & 38,5 & 34 & 65,4 & 69 & 44,2 \\
\hline Tidak Puas & 37 & 71,2 & 32 & 61,5 & 18 & 34,6 & 87 & 55,8 \\
\hline Jumlah & 52 & 100 & 52 & 100 & 52 & 100 & 156 & 100 \\
\hline
\end{tabular}

Tabel 3, menunjukkan sebagian besar responden yang melakukan kunjungan/pemeriksaan antenatal di Puskesmas Karang Intan, Anjir Muara dan Anjir Pasar tidak puas dengan pelayanan antenatal yang diberikan sebanyak 87 orang $(55,8 \%)$.

4. Perspektif Pertumbuhan dan Sumber Daya Manusia (Pendidikan dan pelatihan)

Pada penelitian ini pengukuran tingkat pendidikan yang dimiliki oleh petugas (bidan) yang memberikan pelayanan antenatal care adalah pendidikan Diploma IV Kebidanan dan Diploma III Kebidanan, sedangkan pelatihan yang pernah diikuti oleh petugas (bidan) adalah Asuhan Persalinan Normal (APN) yang diselenggarakan oleh PKRS RS Ulin Banjarmasin, Peningkatan Kapasitas Kompetensi Bidan dan Fasilitator Kesehatan Ibu Dan Anak diselenggarakan oleh Bapelkes Propinsi Kalimantan Selatan.

Penyelenggara. Pendidikan yang diterima oleh bidan sebagian besar dilakukan di Institusi Pendidikan Negeri dan Institusi Swasta yang ada di Provinsi Kalimantan Selatan. Berdasarkan balanced scorecard dilakukan penilaian tingkat pendidikan dan pelatihan yang didapat oleh petugas (bidan), untuk tingkat pendidikan berdasarkan 
ijazah yang dimiliki (Diploma I, Diploma III atau Diploma IV), sedangkan untuk jenis pelatihan di nilai dari sertifikat pelatihan yang dimiliki oleh petugas (bidan).

Pendidikan bidan yang memberikan pelayanan antenatal care adalah 2 orang (67\%) berlatar belakang Diploma IV Kebidanan dan 1 orang (33\%) berlatar belakang Diploma III Kebidanan. Bidan yang memberikan pelayanan antenatal di Puskesmas Karang Intan dan Puskesmas Anjir Pasar memiliki latar belakang D IV Kebidanan dan bidan di Puskesmas Anjir Muara berlatarbelakang D III Kebidanan. Sedangkan pelatihan yang pernah di ikuti oleh bidan yang memberikan pelayanan antenatal baik di Puskesmas Karang Intan ,Puskesmas Anjir Muara dan Anjir Pasar semuanya telah mengikuti pelatihan Asuhan Persalinan Normal (APN) yang diselenggarakan oleh PKRS RS Ulin Banjarmasin, Peningkatan Kapasitas Kompetensi Bidan dan Fasilitator Kesehatan Ibu Dan Anak diselenggarakan oleh Bapelkes Propinsi Kalimantan Selatan.

\section{PEMBAHASAN}

\section{A. Perspektif finansial}

Hasil yang didapatkan sumber biaya operasional pelayanan antenatal berasal dari dana BOK (Bantuan Operasional Kesehatan) masing-masing puskesmas ditemukan tidak ada perbedaan besar, dana yang digunakan untuk pelayanan antenatal. Pada penelitian ini ketiga puskesmas memperoleh dana yang hampir sama. Menurut Azwar (1996) menyatakan bahwa pembiayaan kesehatan harus memenuhi pesyaratan antara lain tersedia dalam jumlah yang cukup, penyebaran dana sesuai kebutuhan dan pemanfaatan tepat pada sasaran. Dalam menilai kinerja organisasi, ukuran-ukuran keuangan saja dinilai kurang mewakili. Hal ini disebabkan karena ukuran-ukuran keuangan memiliki beberapa kelemahan yaitu indikator finansial bersifat historis sehingga hanya mampu memberikan indikator dari kinerja manajemen dan tidak mampu sepenuhnya menuntun organisasi ke arah yang lebih baik, pengukuran lebih berorientasi kepada manajemen operasional dan kurang mengarah kepada manajemen strategis (Mulyadi, 2001).

\section{B. Perspektif bisnis internal yaitu pelayanan antenatal sesuai standar 10T}

Hasil penelitian pada tabel 4.3 didapatkan sebagian besar responden yang melakukan kunjungan / pemeriksaan antenatal di Puskesmas Karang Intan, Anjir Muara dan Anjir Pasar mendapatkan pelayanan sesuai standar 10 T sebanyak 83 orang (53,3\%).

Standar pelayanan antenatal 10T merupakan indikator kualitas pelayanan antenatal, hal ini sesuai dengan ketentuan yang ditetapkan oleh Kementrian Kesehatan (2010), yang diberikan kepada pelanggan (ibu hamil). Adapun standar pelayanan antenatal 10T meliputi : 1) Timbang berat badan dan ukur tinggi badan, 2) ukur Tekanan darah, 3) nilai sTatus gizi, 4) ukur Tinggi fundus uteri, 5) Tentukan posisi fundus uteri, 6) pemberian imunisasi Tetanus toksoid, 7) pemberian Tablet tambah darah, 8) Tes laboratorium sederhana ( $\mathrm{Hb}$, protein urin) dan atau atas indikasi 9HbsAG, HIV, Malaria, TBC), 9) Tatalaksana kasus, 10) Temu wicara. Kualitas pelayanan antenatal juga ditentukan oleh konseling dan pemeriksaan dengan cara pendekatan risiko sangat penting khususnya pada kehamilan yang memiliki faktor risiko (Dasuki, 1997). Tabel 4.5 menunjukan dari 83 responden yang mendapatkan pelayanan antenatal sesuai standar $10 \mathrm{~T}$ seluruhnya $(100 \%)$ memiliki kualitas pelayanan antenatal yang baik. Terdapat hubungan yang bermakna antara pelayanan antenatal sesuai standar 10T dengan kualitas pelayanan antenatal dengan nilai $p=0,000$. Hal ini menunjukkan semakin standar pelayanan antenatal yang diberikan maka semakin baik kualitas pelayanan yang diberikan. 


\section{Perspektif kustomer (kepuasan pasien)}

Hasil penelitian pada tabel 4.4 didapatkan sebagian besar responden yang melakukan kunjungan / pemeriksaan antenatal di Puskesmas Karang Intan, Anjir Muara dan Anjir Pasar tidak puas dengan pelayanan antenatal yang diberikan sebanyak 87 orang $(55,8 \%)$. Responden yang merasa tidak puas dengan pelayanan antenatal yang diberikan lebih banyak di Puskesmas Karang Intan sebanyak 37 orang $(71,2 \%)$.

Berdasarkan hasil kuesioner ketidakpuasan responden terhadap pelayanan yang diberikan dikarenakan ketidakpastian waktu pelayanan, tanggapan petugas terhadap permintaan pasien dengan cepat kurang direspon, perhatian petugas pada pasien, petugas kurang memberikan perhatian secara perorangan, kurang cepatnya pelayanan yang diberikan. Hasil penelitian yang didapat sesuai dengan pendapat Azwar (1996) bahwa kepuasan pasien tidak hanya berdasarkan pada hasil penilaian terhadap keterampilan petugas, tetapi mencakup hubungan petugas dengan pasien, kenyamanan pelayanan dan kebebasan melakukan pilihan, kemampuan dan kompetensi teknis dan efektifitas pelayanan dan keamanan tindakan. Kaplan dan Norton, (2000), pelanggan akan merasa puas jika mendapatkan pelayanan yang mereka butuhkan sesuai dengan ketepatan waktu, biaya dan kualitas pelayanan. Salah satu aspek untuk mengukur proses pelayanan adalah responsiveness yaitu kesediaan untuk membantu customer (ibu hamil) dalam memberikan pelayanan yang cepat terhadap setiap yang dilayani (Parasuraman, 1998).

\section{Perspektif Pendidikan dan Pelatihan}

Hasil penelitian didapatkan pendidikan bidan yang memberikan pelayanan antenatal care adalah 2 orang (67\%) berlatar belakang Diploma IV Kebidanan dan 1 orang (33\%) berlatar belakang Diploma III Kebidanan. Bidan yang memberikan pelayanan antenatal di Puskesmas Karang Intan dan Puskesmas Anjir Pasar memiliki latar belakang D IV Kebidanan dan bidan di Puskesmas Anjir Muara berlatarbelakang D III Kebidanan.

Pelatihan yang pernah di ikuti oleh bidan yang memberikan pelayanan antenatal baik di Puskesmas Karang Intan ,Puskesmas Anjir Muara dan Anjir Pasar semuanya telah mengikuti pelatihan Asuhan Persalinan Normal (APN) yang diselenggarakan oleh PKRS RS Ulin Banjarmasin, Peningkatan Kapasitas Kompetensi Bidan dan Fasilitator Kesehatan Ibu Dan Anak diselenggarakan oleh Bapelkes Propinsi Kalimantan Selatan. Mulyadi dan Setyawan (2000) mengemukakan supaya petugas dapat menjalankan dan mematuhi pelayanan sesuai standar ditentukan dengan efektivitas pendidikan yang diterimanya. Mulyadi (2001), tingginya pengetahuan yang dimiliki petugas ditentukan oleh efektivitas pendidikan dan pelatihan yang diselenggarakan oleh organisasi. Sasongko (2000), menyatakan balanced scorecard tidak hanya menekankan pada output organisasi saja tetapi juga infrastruktur organisasi itu sendiri itu sendiri yang terdiri dari orang, sistem dan prosedur. Thomas (1995), pelatihan merupakan suatu keharusan bila organisasi menghendaki kinerja yang baik dari para pegawainya, kendati mengandung untung rugi pelatihan lebih banyak memberikan keuntungan. Pelatihan akan meningkatkan kepuasan customer dan meningkatkan pelatihan petugas (Mayer, 1998).

\section{KESIMPULAN}

Kesimpulan penelitian ini antara lain:

A. Perspektif finansial berupa dana operasional untuk pelayanan antenatal bersumber dari dana BOK (Bantuan Operasional Kesehatan).

B. Perspektif proses bisnis internal berupa proses penerapan pelayanan antenatal sesuai standar 10 T pada Puskesmas Karang Intan lebih ditekankan pada temu wicara berupa 
bidan mendiskusikan masalah yang dialami oleh ibu hamil yang belum maksimal dilaksanakan.

C. Perspektif customer berupa kepuasan pelanggan pada Puskesmas Karang Intan, Puskesmas Anjir Pasar dan Anjir Muara lebih ditekankan pada ketidakpuasan responden terhadap pelayanan yang diberikan dikarenakan ketidakpastian waktu pelayanan, tanggapan petugas terhadap permintaan pasien dengan cepat kurang direspon, perhatian petugas pada pasien, petugas kurang memberikan perhatian secara perorangan, kurang cepatnya pelayanan yang diberikan.

D. Perspektif pertumbuhan dan sumber daya manusia berupa pendidikan dan pelatihan Puskesmas Anjir Muara ditekankan pada peningkatan jenjang pendidikan ke Diploma IV Kebidanan, sedangkan Puskesmas Anjir Pasar dan Puskesmas Karang Intan sudah memiliki jenjang pendidikan Diploma IV Kebidanan.

\section{UCAPAN TERIMAKASIH}

Penelitian ini dapat diselesaikan dengan bantuan berbagai pihak dan penulis mengucapkan terimakasih kepada :

1. Direktur Poltekkes Kemenkes Banjarmasin

2. Ketua Jurusan Kebidanan

3. Responden Penelitian

4. Kepala Puskesmas Karang Intan, Anjir Muara dan Anjir Pasar

5. Semua pihak yang tidak bisa penulis sebutkan satu persatu

\section{DAFTAR PUSTAKA}

1. Badan Pusat Statistik (BPS) dan ORC Macro Survei Demografi dan Kesehatan Indonesia, Calverton, Maryland USA: ORC Macro, 2007.

2. Badan Perencanaan Pembangunan Nasional (Bappenas) Laporan Perkembangan Tujuan Pembangunan Milenium Indonesia. Jakarta, 2005.

3. Kemenkes RI, Kemenkes Luncurkan RAN PPAKI, tersedia di http://www.mutupelayanankesehatan.net/index.php/berita/893-kemenkes, di akses tanggal 20 Oktober 2015, 2012.

4. Herusantosa,T., Hakimi, M., , Hubungan Kualitas Pelayanan Antenatal dengan Kematian Perinatal di Kabupaten Sukoharjo, Universitas Gadjah Mada, Yogyakarta, 2006.

5. Ernawati, Evaluasi Kinerja Pelayanan Antenatal antara Puskesmas Cakupan Tinggi dengan Puskesmas Puskesmas Cakupan Rendah menggunakan Pendekatan Balanced Scorecard di Kabupaten Bekasi, 2008.

6. Azwar, A, Pengantar Administrasi Kesehatan, Edisi ketiga. Bina Putra, Jakarta, 1996.

7. Dasuki, D., Hakimi, M., Wilopo, S .A., Kurniawati, L Evaluasi Efektifitas Perawatan Kehamilan Di Kabupaten Purworejo Jawa Tengah. Berita Kedokteran Masyarakat, XIII:16-20, 1997.

8. Mulyadi, Balanced Scorecard: Alat manajemen Kontemporer untuk Pelipatgandaan Kinerja Keuangan Perusahaan. Salemba Empat, Jakarta, 2001.

9. Parasuraman, A (1998) Customer Service In Business to Business Market; An Agenda For Research, University of Miami, Florida USA, Journal of Busness dan Industrial Marketing, 13 (4/5): 309-321.

10. Sasongko, N, Balanced Scorecard Perspektif pembelajaran dan Pertumbuhan (Learning and Growth Perspective). Workshop Akuntansi Manajemen. Fakultas Ekonomi Universitas Jendral Achmad Yani, 2000. 